As-Syifaa Vol 07 (02) : Hal. 209-218, Desember 2015

ISSN : 2085-4714

\title{
ALTERNATIF SPLINTING PADA KEGOYANGAN GIGI AKIBAT PENYAKIT PERIODONTAL
}

\author{
Lilies Anggarwati Astuti
}

\author{
Fakultas Kedokteran Gigi Universitas Muslim Indonesia Makassar \\ Email : liliesanggarwatigauk@yahoo.com
}

\begin{abstract}
Introduction: Periodontal disease is a disease of inflammation of the tissues around the tooth that originated from inflammatory gingival and continues to the periodontal structures other periodontal ligament and cementum, and the alveolar bone. Loosening of the teeth is one of the symptoms of periodontal disease characterized by loss of bonding as well as vertical bone damage. Loosening can be caused by damage to the bone that supports the teeth, trauma from occlusion, and the presence of inflammation of the gingiva to the expansion of the network of supporters who are more patologik and processes in the jaw. Purpose: one of the ways to control and stabilize the loosening of the teeth is splinting. Splinting is indicated on the State loosening teeth degree 3 with severe bone damage. Literature review: Periodontal splint is a tool that can be used for stabilization or loosening of teeth that immobilisasi experience. Splint consists of temporary and permanent splint splint. Indication temporary splint is for stabilization of teeth rocking before and during therapy with the goal to reduce the peridontal trauma at the time of care and speed up the healing process, such as the ligature wire splint. Discharging permanent splint is part of this phase of the restoration or reconstruction phases of periodontal care. Permanent Splint is extremely limited usage. Used when actually used to increase the stability of pressure oklusal. Summary: the selection of the alternatives of periodontal splint adapted on certain conditions, such as economic status and health status of the patient.
\end{abstract}

Key words: Splinting, loosening of teeth, periodontal disease.

\section{PENDAHULUAN}

Penyakit periodontal

merupakan penyakit peradangan pada jaringan sekitar gigi yang berawal dari inflamasi gingiva dan berlanjut ke struktur jaringan penyangga gigi lainnya yaitu sementum, ligamentum periodontal dan tulang alveolar. Kegoyangan gigi merupakan salah satu gejala penyakit periodontal yang ditandai dengan hilangnya perlekatan serta kerusakan tulang vertikal. Kegoyangan dapat disebabkan adanya kerusakan tulang yang mendukung gigi, trauma dari oklusi dan adanya perluasan peradangan dari gingiva ke jaringan pendukung yang lebih dalam serta proses patologik rahang. ${ }^{1}$ Menurut Fedi dkk, kegoyangan gigi diklasifikasikan 
menjadi tiga derajat. Derajat 1 yaitu kegoyangan sedikit lebih besar dari normal. Derajat 2 yaitu kegoyangan sekitar $1 \mathrm{~mm}$, dan derajat 3 yaitu kegoyangan sekitar > $1 \mathrm{~mm}$ pada segala arah dan gigi dapat ditekan ke arah apikal. ${ }^{1}$

Salah satu cara untuk
mengontrol dan menstabilisasi
kegoyangan gigi adalah splinting. Splinting diindikasikan pada keadaan kegoyangan gigi derajat 3 dengan kerusakan tulang berat. Adapun indikasi utama penggunaan splint dalam mengontrol kegoyangan yaitu imobilisasi kegoyangan yang menyebabkan ketidaknyamanan pasien serta menstabilkan gigi pada tingkat kegoyangan yang makin bertambah. Ditambahkan oleh Strassler dan Brown splinting juga digunakan untuk mengurangi gangguan oklusal dan fungsi mastikasi. $^{1}$

Splinting dilakukan pada terapi inisial (fase etiotropik) dalam rencana perawatan penyakit periodontal. Tindakan yang dilakukan pada fase pertama adalah pemberian kontrol plak yang meliputi motivasi edukasi dan instruksi, skeling dan penghalusan akar, splinting dan terapi oklusal, serta pemberian terapi penunjang berupa antimikroba. $^{1}$
Splint, menurut Glossary of Periodontic Terms (1986) merupakan "sebuah piranti yang didesain untuk menstabilkan gigi disertai mobilitas". Splint dapat dibuat dalam bentuk yang menyatu dengan tumpatan komposit, gigitiruan jembatan, protesa sebagian lepasan, dll. ${ }^{2}$

\section{TUJUAN PENELITIAN}

Tujuan penulisan ini adalah untuk mengetahui splinting yang merupakan salah satu alternatif kegoyangan gigi adalah pada penyakit periodontal. $^{1}$

\section{TINJAUAN PUSTAKA}

Periodontal splint adalah alat yang dapat digunakan untuk stabilisasi atau immobilisasi gigi yang mengalami kegoyangan. Splint terdiri dari splint sementara dan splint permanen. Indikasi splint sementara adalah untuk stabilisasi gigi goyang sebelum dan selama terapi peridontal dengan tujuan unutk mengurangi trauma pada waktu perawatan dan mempercepat proses penyembuhan, contohnya wire ligature splint. Pemakaian splint permanen merupakan bagian dari fase restorasi atau fase rekonstruksi dari perawatan periodontal. Splint permanen sangat terbatas penggunaannya. Digunakan bila benar-benar dipergunakan untuk menambah stabilitas tekanan oklusal. ${ }^{1}$ 
Splinting biasanya dilakukan pada fase terapi inisial, dimana terapi inisial bertujuan untuk membuang semua faktor lokal yang menyebabkan peradangan gingival serta pemberian instruksi dan motivasi pasien dalam melakukan kontrol plak. Terapi inisial juga disebut sebagai fase etiotropik karena bertujuan untuk menghilangkan faktor etiologi penyakit periodontal. Terapi inisial mencakup kontrol plak yang meliputi motivasi, edukasi dan instruksi dari pasien, skeling dan penghalusan akar, rekonturing restorasi, pembuangan karies, pemberian antimikroba serta evaluasi jaringan. Pencapaian perawatan melalui bedah periodontal dapat dilakukan bilamana terapi inisial berhasil dengan baik. ${ }^{1}$

Splinting biasanya dilakukan pada fase inisial, sebelum fase bedah, baik berupa splinting sementara maupun splinting permanen. Beberapa penelitian menunjukkan splinting dapat meningkatkan resistensi jaringan terhadap kerusakan periodontal lebih lanjut dan mempercepat respon penyembuhan. ${ }^{1}$

Untuk menjelaskan apakah terdapat beberapa indikasi untuk splinting, seseorang harus mempertimbangkan penyebab mobilitas gigi: ${ }^{3}$

1. Kehilangan struktur pendukung secara kuantitatif akibat periodontitis

2. Perubahan struktur pendukung secara kualitatif akibat trauma from occlusion

3. Trauma jangka pendek pada periodonsium akibat perawatan periodontitis.

4. Kombinasi penjelasan di atas.

Gigi yang mengalami mobilitas dengan derajat mobilitas yang tidak meningkat, umumnya tidak membutuhkan splinting. Gigi dengan peningkatan mobilitas akibat trauma oklusal harus dirawat dengan penyesuaian oklusal, bukan dengan splinting (Vollmer \& Rateischak 1975). Meskipun tidak benar bahwa gigi yang mengalami mobilitas dapat diimobilisasi dengan splinting, dan bahwa splinting memberikan kenyamanan bagi pasien, splinting tidak menyebabkan stabilisasi biologis gigi jangka panjang (Galler dkk, 1979; Rateitschak 1980). ${ }^{3}$ 
Skema berikut merupakan klasifikasi kemungkinan dilakukannya splinting: ${ }^{3}$

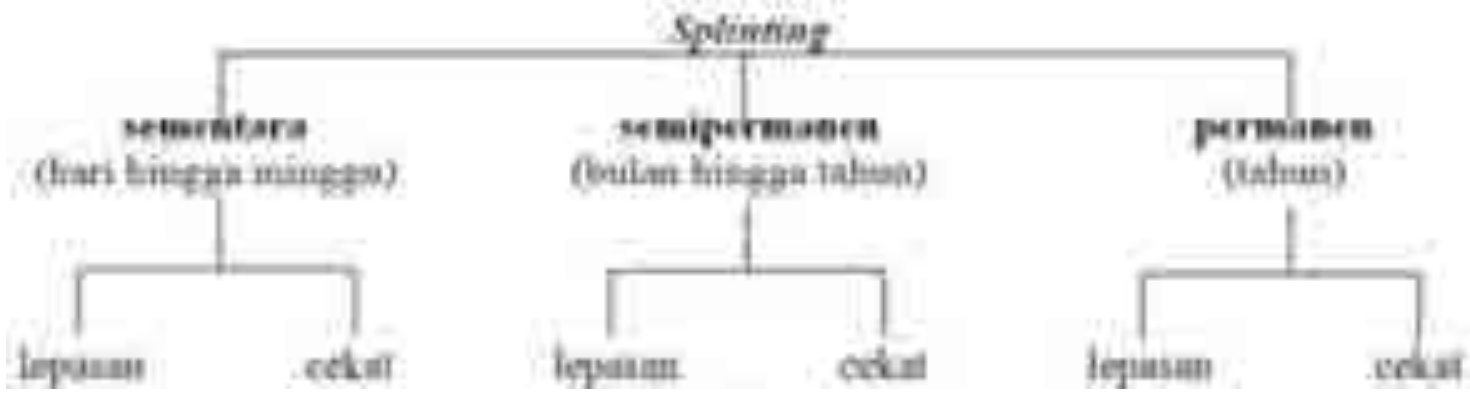

Indikasi untuk beragam jenis splinting ${ }^{3}$

Splinting sementara atau semipermanen diindikasikan untuk gigi dengan mobilitas parah sebelum maupun selama terapi periodontal. Splinting jenis ini dapat menurunkan trauma perawatan.

Splinting semipermanen atau permanen dapat digunakan untuk menstabilkan gigi dengan mobilitas tinggi sehingga mengganggu pengunyahan pasien. Retensi ortodontik juga dapat dianggap sebagai jenis splinting semipermanen/permanen.

Splinting permanen digunakan selama rehabilitasi rongga mulut kompleks di mana gigi penyangga mengalami mobilitas tinggi atau di mana gigi penyangga yang sedikit harus mendukung seluruh protesa, terutama ketika gigi penyangga memiliki dukungan periodontal yang minimal, namun telah berhasil dirawat secara periodontal. Jika beberapa gigi tidak di-splinting, akan terjadi bahaya peningkatan mobilitas gigi yang terus berlanjut. (Nyman \& Lyndhe 1979).

\section{Splinting Sementara ${ }^{3}$}

Ligatur kawat sederhana (Gbr. 1) dapat berfungsi sebagai splint cekat selama beberapa hari hingga beberapa minggu. Ligatur kawat sudah jarang digunakan sekarang ini, terutama karena pertimbangan estetik. Splint cekat sementara yang paling umum digunakan, yaitu splint resin komposit etsa-asam tanpa preparasi gigi (Gbr. 2). Beberapa splint dapat diaplikasikan dengan cepat dan mudah disertai penggunaan rubber dam dalam rongga mulut; namun, splinting ini merupakan pengukuran sementara karena adhesi resin terhadap struktur gigi tidak terlalu kuat tanpa tambahan retensi mekanis yang diberikan oleh preparasi kavitas, groove, dll. Fraktur splint umum terjadi jika lebih dari 3-4 gigi yang terlibat dalam satu unit splinting. 


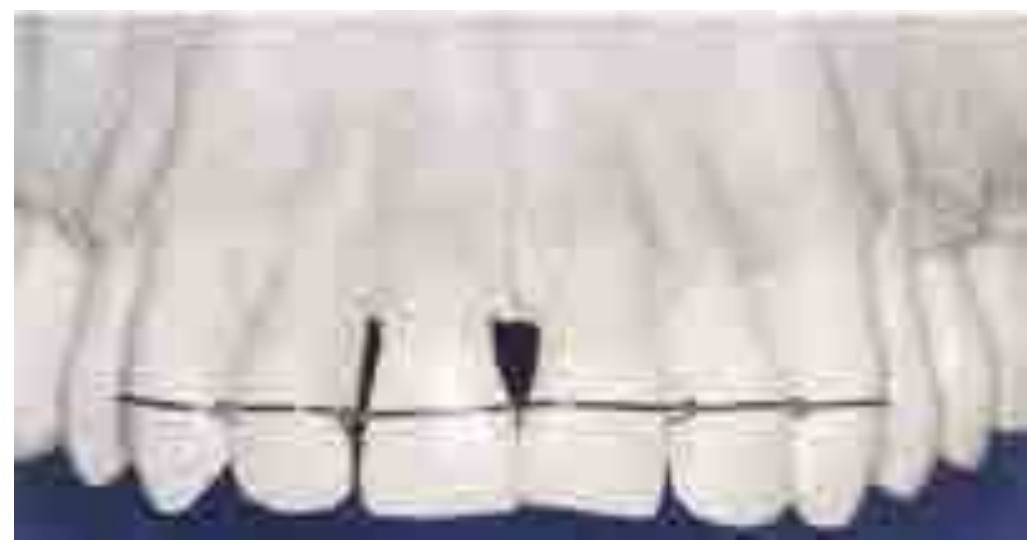

Gambar 1. Splint kawat. Kawat besi lunak (diameter $0.04 \mathrm{~mm}$ ) dililitkan mengelilingi permukaan fasial dan oral gigi yang akan di-splinting, kemudian ligatur dikencangkan dengan memuntir ujung kawat. Stabilisasi gigi individual dapat dicapai dengan mengaplikasikan ligatur interdental. Resin etsa-asam dapat diaplikasikan pada permukaan labial tiap gigi (Gbr. 6) untuk mencegah kawat meluncur ke arah apikal. Splint kawat tidak memberikan perlindungan terhadap tekanan oklusi

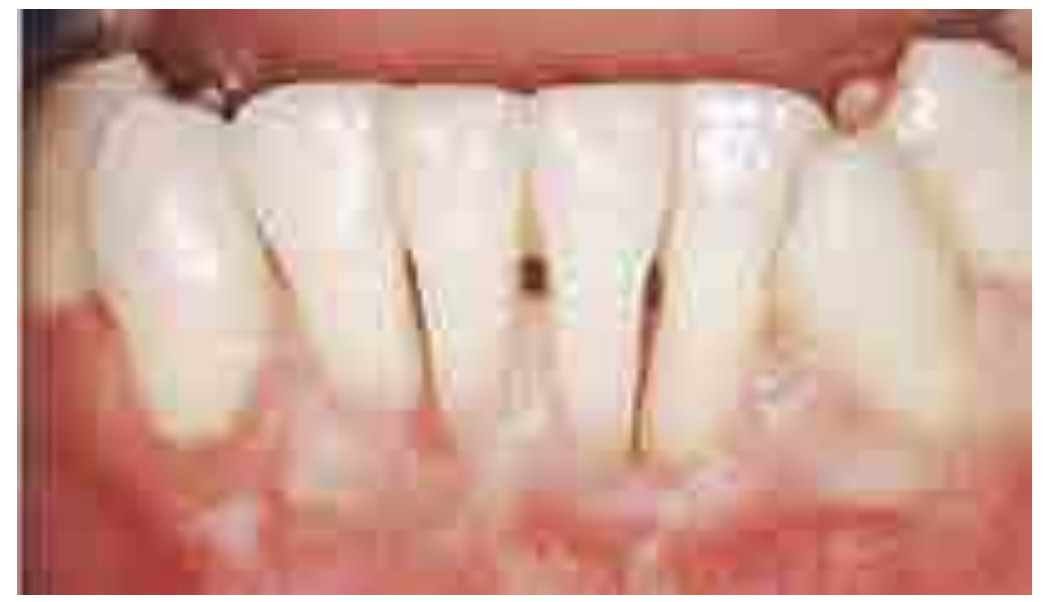

Gambar 2. Splint resin komposit, tanpa preparasi gigi. Setelah gigi dibersihkan secara menyeluruh, permukaan interproksimal diaplikasikan etsa-asam dan resin. Daerah apikal ruang interdental harus dibiarkan terbuka untuk memelihara kebersihan yang baik.

Splint sementara lepasan dapat terbuat dari akrilik bening yang ditarik di dalam vakum pada model studi (Gbr. 3). Splint ini kadang diindikasikan untuk stabilisasi sementara gigi individu untuk jangka waktu yang singkat. Jenis splint ini sebelumnya digunakan sebagai "bite guard" pada perawatan parafungsi rongga mulut, namun dengan keberhasilan yang sangat sedikit. 


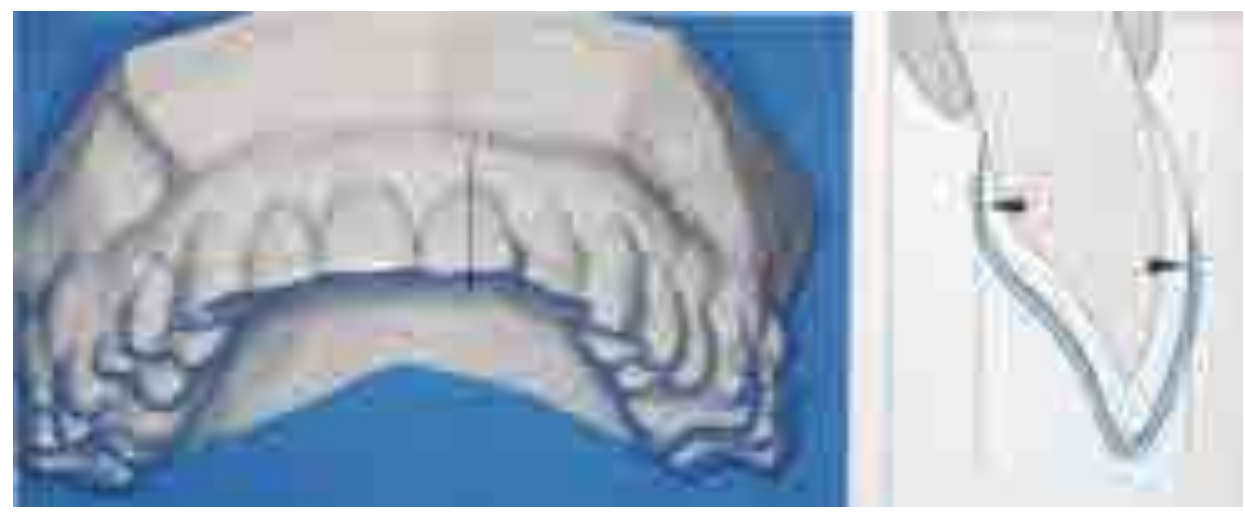

Gambar 3. Vacuum formed removable acrylic splint. Splint ini dapat digunakan untuk retensi atau stabilisasi gigi jangka pendek. Tepi splint harus melebihi tinggi kontur tiap gigi (tanda panah pada skema) baik pada permukaan labial dan lingual, untunk memberikan retensi yang aman.

\section{Splinting Semipermanen ${ }^{3,4}$}

1. Peningkatan mobilitas gigi sebagai akibat penurunan periodonsium dapat diterima selama oklusi tetap stabil dan kenyamanan pengunyahan tidak terganggu.

2. Relasi yang tidak menguntungkan antara mahkota klinis dan panjang gigi secara keseluruhan dapat menyebabkan tekanan yang berpengaruh pada puncak alveolar dan pada apeks selama fungsi: sehingga disebut trauma oklusal sekunder.

3. Pada kasus splinting gigi ini dalam menurunkan ruang ligamentum periodontal, karena tekanan yang menganggu tersebar pada beberapa gigi.

Indikasi untuk splinting semipermanen:

1. Penurunan gigi-jaringan pendukung yang signifikan

2. Mobilitas gigi yang progresif
3. Risiko kehilangan gigi selama fungsi atau perawatan

\section{Prosedur:}

1. Splinting menggunakan komposit setelah pengetsaan daerah email yang cukup besar pada gigi yang akan di-splinting dan gigi tetangga. Splint dapat diperkuat menggunakan serat karbon atau dilindungi dengan kerangka logam atau kerangka akrilik.

2. Pembentukan unit kecil yang mengalami mobilitas sangat menguntungkan; jika lebih dari tiga gigi yang disatukan, risiko fraktur (pada gigi yang kokoh) dianggap dapat mengalami peningkatan.

3. Oklusi harus diperiksa dengan teliti; terutama pada gigi anterior maksila dapat menimbulkan keadaan yang tidak dapat diterima secara estetik.

4. Kebersihan periodontal tidak boleh terganggu; pembersihan embrasur 
dengan menggunakan sikat interdental atau dental floss (Superfloss) di rumah harus memungkinkan.

Splint semipermanen cekat yang sangat sering digunakan pada daerah anterior adalah splint resin komposit etsa-asam yang diaplikasikan setelah preparasi gigi. splint ini dapat berfungsi selama beberapa bulan atau bahkan tahun. Kadang sangat memungkinkan untuk melepas restorasi anterior yang lama dan menggunakan preparasi kavitas pada splint. Teknik aplikasi ini serupa dengan penempatan restorasi resin komposit menggunakan etsa-asam sebelum perawatan.

Pada daerah anterior mandibula, splint resin intrakoronal yang menyatu dengan serat poliester telah terbukti sangat berguna (Grau \& Lutz 1982). Resin polimerisasi-ringan umumnya digunakan untuk jenis splint ini karena waktu kerja yang panjang.
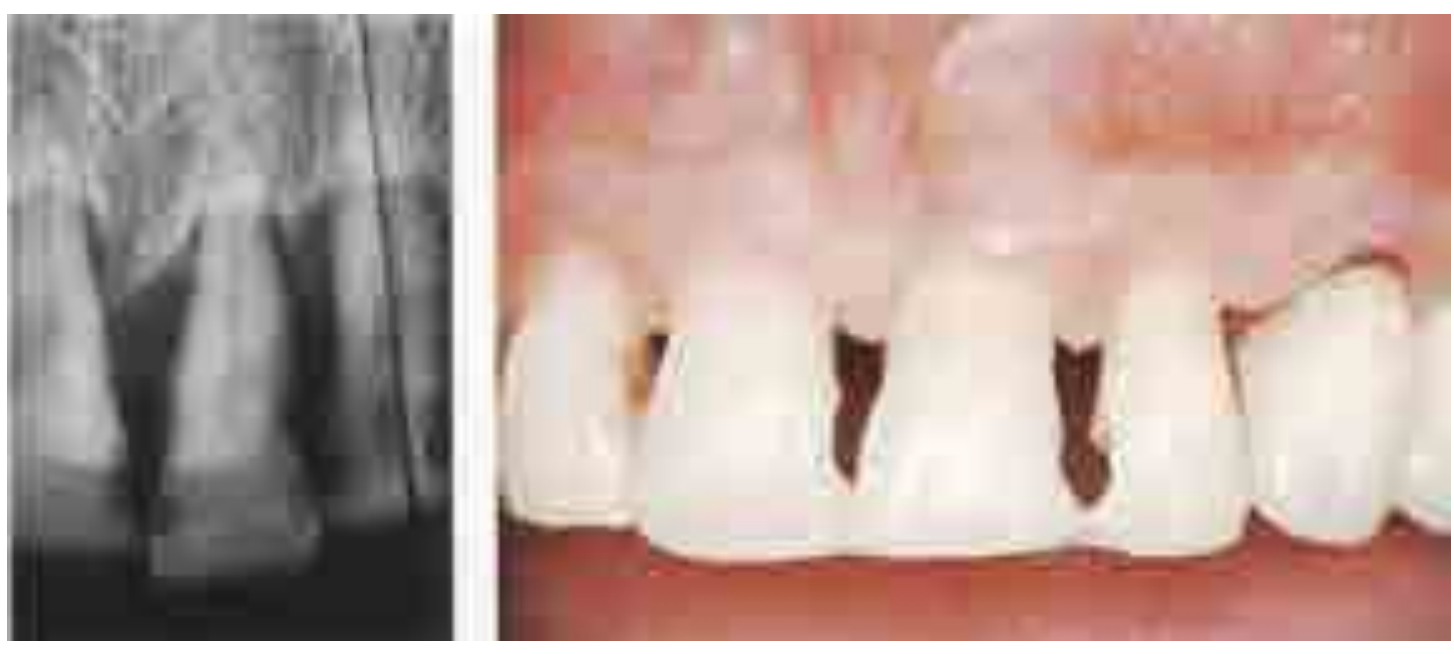

Gambar 4. Splint resin komposit dengan preparasi gigi. Wanita berusia 38 tahun ini tidak ingin mengubah keinginannya bahwa gigi anterior maksila yang terlibat dan hampir tidak dapat diharapkan tersebut harus dipertahankan. Setelah terapi awal, gigi 11, 21, dan 22 dengan mobilitas tinggi harus distabilisasi dengan melepaskan resin Klas III yang lama dan menggunakan preparasi kavitas untuk retensi splint resin etsa-asam. Splint tetap berada pada tempatnya hingga prognosis definitif seluruh gigi-geligi dapat ditentukan. 


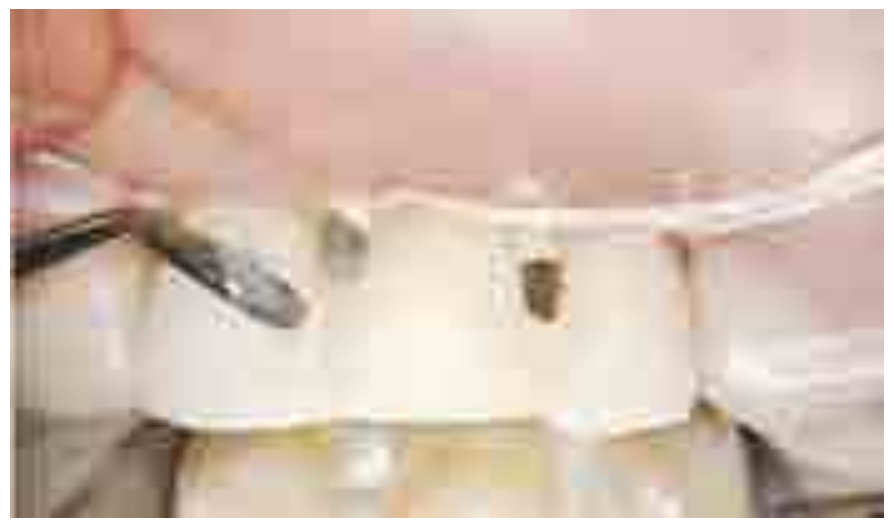

Gambar 5. Aplikasi splint dengan rubber dam. Setelah dilakukan pengetsaan tepi kavitas menggunakan asam fosforik, preparasi kavitas dan bagian koronal ruang interdental ditumpat dengan resin komposit light-cured kemudian dikilapkan.
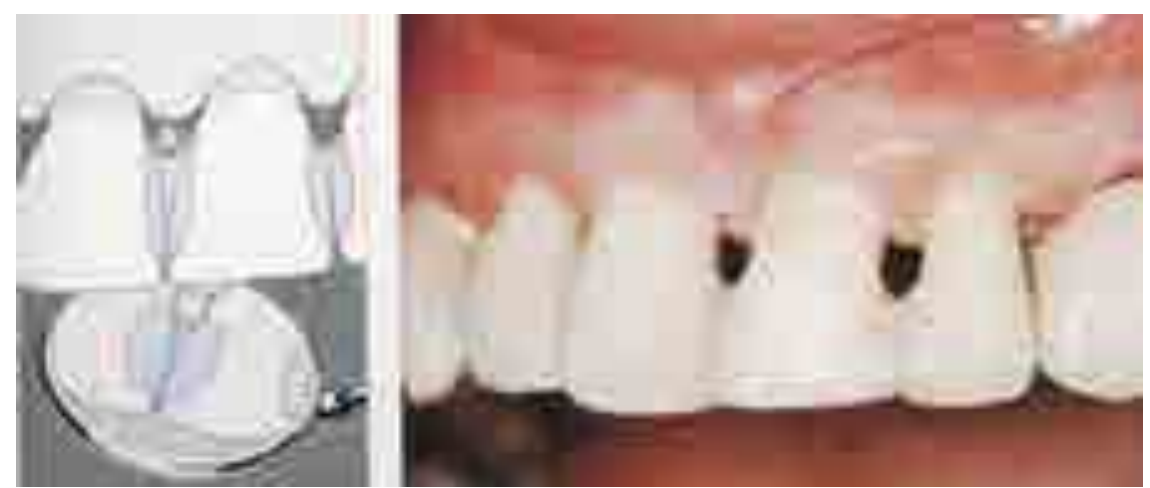

Gambar 7. Mobilitas gigi yang sangat mengganggu. Wanita berusia 25 tahun ini menunjukkan adanya gingivoperiodontitis ulseratif (ANUG) pada tahap interval. Radiografi menunjukkan kehilangan tulang sedang hingga parah pada daerah anterior mandibula. Gigi 41, 31, dan 32 mengalami mobilitas dan nonfungsional tinggi. Splint semipermanen diperkuat fiber, intrakoronal diindikasikan pada perawatan ini, agar gigi tetap berada di tempatnya setidaknya hingga rencana perawatan, prognosis definitif, dan terapi aktif dapat diselesaikan.

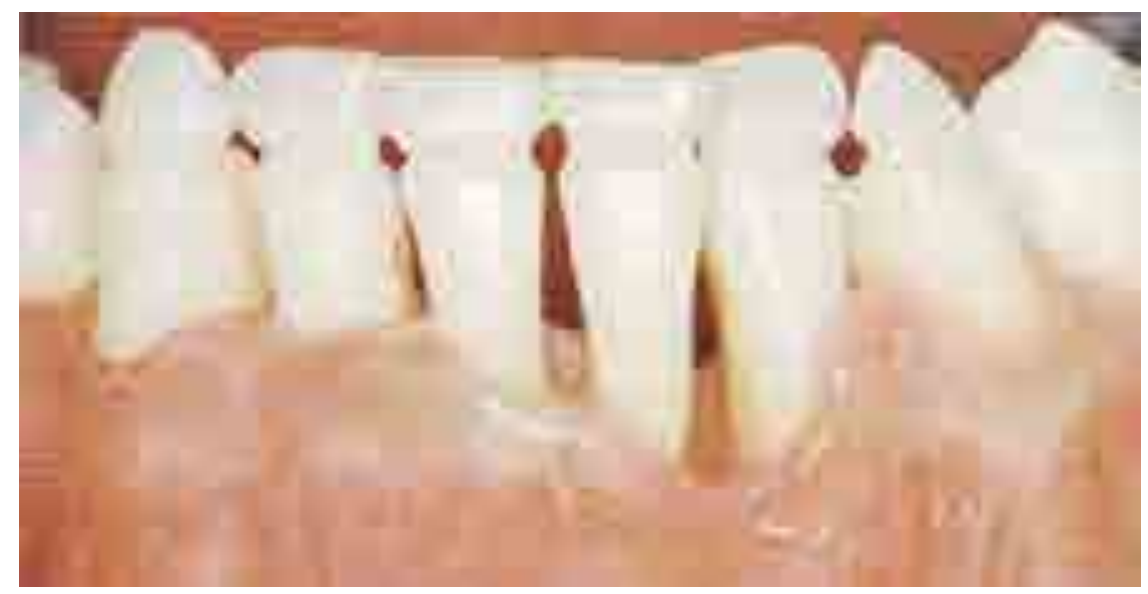

Gambar 8. Splinting intrakoronal - Preparasi groove. Dengan menggunakan bur intan bulat kecil, groove dipreprasi pada email/dentin dengan kedalaman 0.7-1.0 $\mathrm{mm}$ pada ketinggian titik kontak interdental secara menyeluruh mengelilingi tiap gigi. Tepi groove dibulatkan dan base diaplikasikan untuk melindungi pulpa ketika groove meluas hingga dentin. 


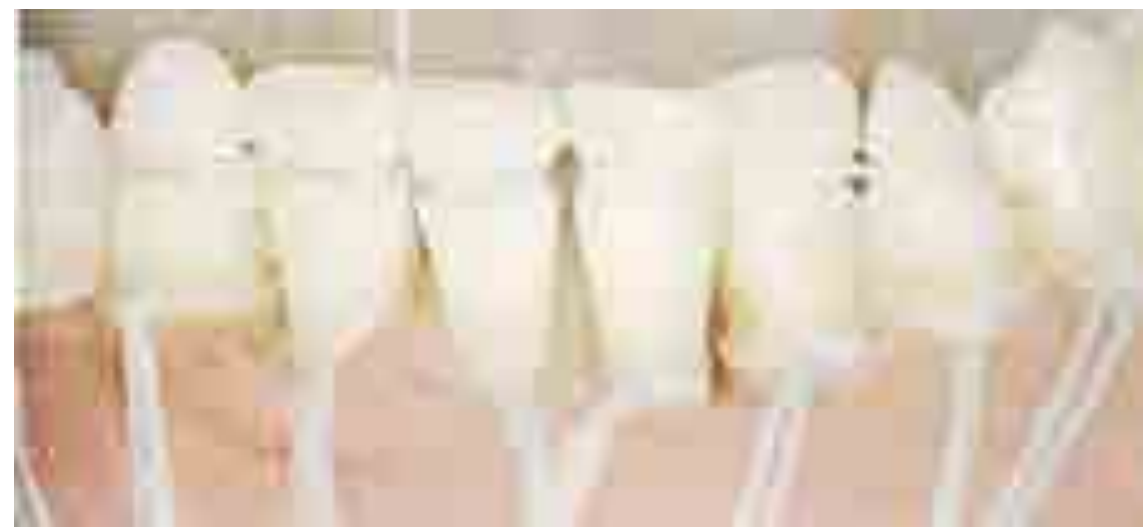

Gambar 9. Etsa asam - Pengaplikasian ligatur poliester. Sebanyak dua splint, masingmasing menyatukan tiga gigi, kemudian dibuat. Ligatur Kevlar tear-resistant pertama-tama dilapisi menggunakan monomer resin (kanan), kemudian diaplikasikan pada gigi seperti angka 8 yang diulang-ulang dan diikat. Perawatan ini dilakukan dengan memasang rubber dam (perhatikan floss pada daerah servikal tiap gigi untuk menahan rubber dam tepat pada tempatnya) untuk memastikan daerah kerja yang kering.

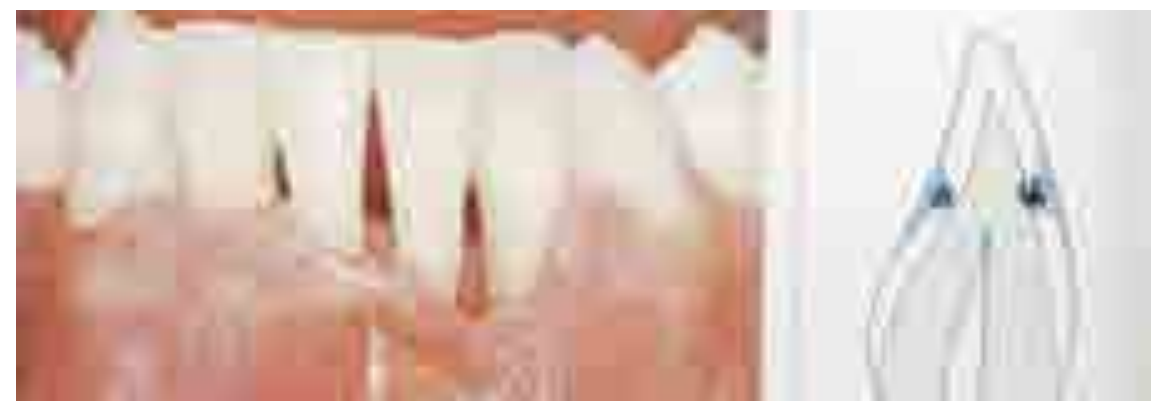

Gambar 10. Splint intrakoronal. Tepi groove yang telah dihaluskan dan telah dietsa (berwarna merah pada skematik) diulasi dengan monomer sebelum ditambahkan dengan resin light-cured (biru). Setelah dihaluskan dan dikilapkan splint resin intrakoronal hampir tidak terlihat secara klinis. Fiber yang menyatu dengan baik menurunkan bahaya fraktur resin.

\section{KESIMPULAN}

Adapun simpulan dari penulisan ini adalah:

1. Pemilihan alternatif splint periodontal disesuaikan pada kondisi-kondisi tertentu, misalnya status ekonomi dan status kesehatan pasien.

2. Splint yang tidak mengganggu secara fungsional atau kosmetik dapat dibiarkan in situ secara permanen.

\section{DAFTAR PUSTAKA}

1. Suwandi Trijani. The Initial Treatment of Mobile Teeth Closure Diastema in Chronic Adult Periodontitis. PDGI Jour 2010;59:105-109.

2. Lindhe J. Nyman S. Toothsupported fixed partial dentures. In: Lindhe J, Lang NP, Karring T, editors. Clinical Periodontology and Implant Dentistry. $5^{\text {th }} \mathrm{Ed}$. Oxford: 
Alternatif splinting pada kegoyangan gigi akibat penyakit periodontal

Blackwell Munksgaard; 2008. P.1129.

3. Rateitschak EM, Wolf HF, Hassel TM. Color Atlas of Periodontology.
New York: Georg Thieme Verlag Stuttgart; 1985. P.291-4.

4. Mueller HP. Periodontology: the Essential. Germany: Druckhaus Gutz. 2005. P. 177-9. 